\title{
OPEN OCEAN DEEP CONVECTION, MEDITERRANEAN AND GREENLAND SEAS
}

\author{
F. SCHOTT, M. VISBECK and U. SEND \\ Institut für Meereskunde an der Universität Kiel \\ Diisternbrooker Weg 20 \\ 2300 Kiel 1 \\ Germany
}

\begin{abstract}
Recent observations within deep convection regimes of the Gulf of Lions and Greenland Sea all confirm the existence of small-scale plumes of only a few $100 \mathrm{~m}$ horizontal scale during cooling periods, in agreement with scaling arguments and non-hydrostatic modelling results. The integral effect of the plumes is that of a mixing agent rather than carrying water downward in a mean motion. It depends on the intensity and duration of the cooling how complete the mixing within the depth range of the plumes is. In the Greenland Sea, the role of the ice through brine rejection was found to be important in the preconditioning period (November - February) rather than for the deep convection itself (March) which occurred when the water was ice-free.

After the convection period water masses are exchanged with the environment through baroclinic instability, causing increased deep $T, S$ variance on a larger scale that continues to exist well into the next summer, allowing identification of previous-winter convection activity.
\end{abstract}

\section{Introduction}

Deep convection in the open ocean occurs in only a few selected areas: prominent examples are the Labrador Sea, the central Greenland Sea and the northwestern Mediterranean. Although the important role of convection areas in modifying water masses of the deep ocean was long understood from observed parameter distributions (e.g., Nansen, 1906), details of what occurs in convection regimes have escaped observation for a long time. With shipboard methods, open ocean deep convection is difficult to observe: it occurs only sporadically over brief periods of time, mostly in remote areas, in hostile environment, during winter and storm events. As regards deployment of moored instruments in a potential convection region over the extent of the winter period these were, until quite recently, inadequate to measure vertical motions over extended durations with the required accuracy.

The first documentation on the development and timescales of open-ocean deep convection was provided by the Medoc 1969 experiment in the Gulf of Lions, northwestern Mediterranean, where it was shown that a homogeneous region of some tens of kilometers horizontal extent opened up upon surface forcing by strong and cold Mistral winds (Medoc group, 1970). The water was mixed down within a few days to near $2000 \mathrm{~m}$, but a stratified layer remained intact underneath. In subsequent studies in the Gulf of Lions it was discovered that deep convection in late winter is a fairly regular event, occurring typically at the end of the winter period, between late January and early March (e.g., Gascard 1973, 1978; Leaman and Schott, 1991).

Similarly, the existence of deep-mixed water columns was documented for the Labrador Sea where it was shown that substantial interannual variations occurred in the T,S properties for different convection years (Lazier, 1973; Clarke and Gascard, 1983) and that a surface mixed-layer salinity decrease, caused by ice import during the time of the "Great Salinity 
Anomaly" (Dickson et al., 1988), shut down convection entirely during the early seventies (Lazier, 1980). In the Greenland Sea, deep-mixed water columns eluded observational efforts until quite recently: A large survey during the winter of 1982 did not detect any evidence of deep convection (Clarke et al., 1990); in winter 1988 homogeneous stratification was only found at a single station out of a hydrographic survey and only down to $1300 \mathrm{~m}$ (Rudels et al., 1989). The most recent large hydrographic survey, in the context of the Greenland Sea Project (GSP group, 1990) during the winter of 1988/89, again found only sporadic evidence for mixing to intermediate depths (Rhein, 1991). Convection activity, its occurrence, scales and integral effects in the northwestern Mediterranean and in the Greenland Sea will be reviewed in the following, based on recent observations.

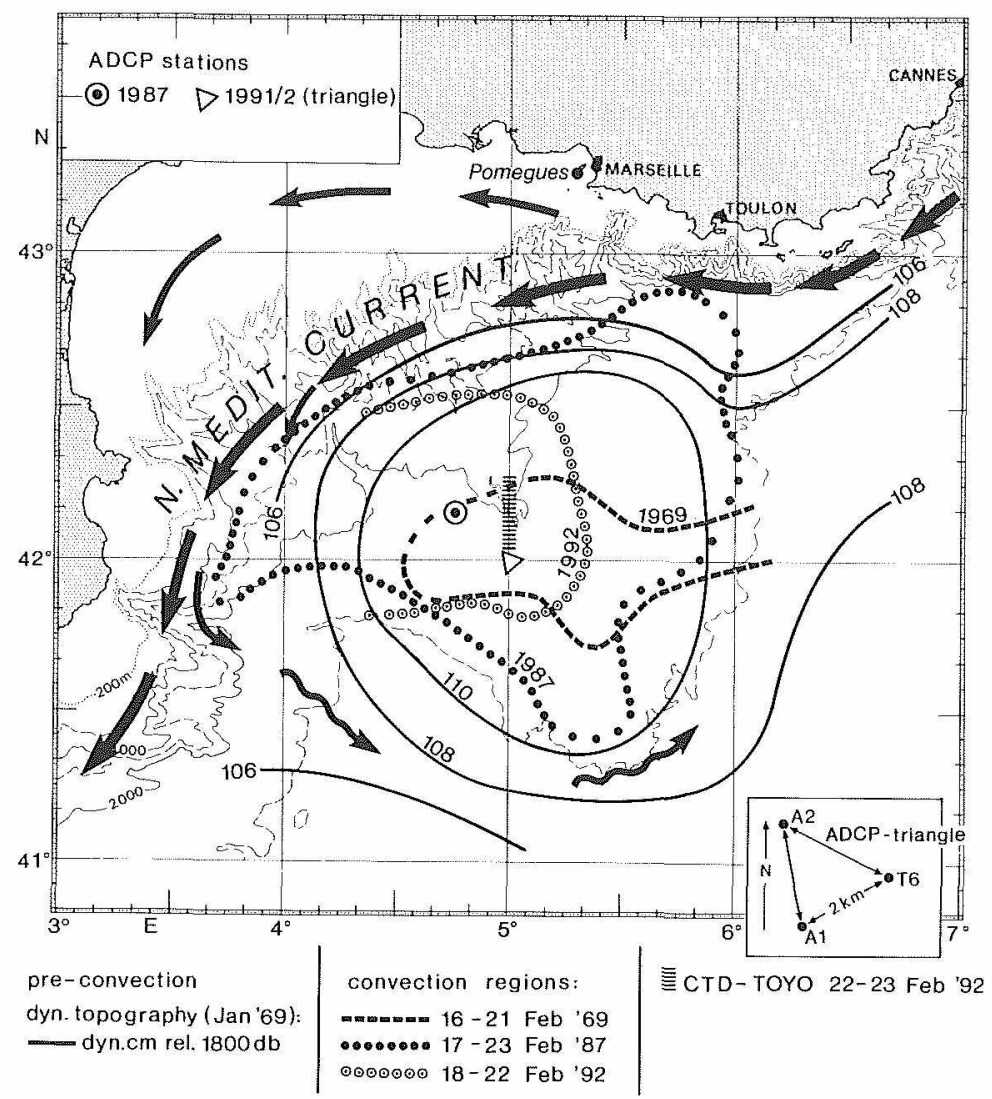

Figure 1: Topography of the Gulf of Lions and circulation of the NW Mediterranean Current. Preconditioning dome shown by dynamic topography of Jan. 1969 (after Sankey, 1973). Extents of deep-mixed areas in Feb. 1969, 1987 and 1992 are marked. Note positions of ADCP station in 1987 (Fig.4), of small-scale ADCP triangle in 1991/92 (stations A1,A2,T6, in inset; Figs. 5,6,) and of CTD-TOYO section (Fig.7) near 42N,5E. 
These investigations were facilitated by the advent of new technologies, compared to the earlier studies. Particularly, acoustic Doppler current profilers (ADCPs) have enabled us to record vertical velocity fluctuations every few minutes over entire winter periods at a vertical resolution of a few meters over depth ranges of hundreds of meters. Although the accuracies of these instruments are still marginal for the determination of event-mean vertical velocities, a significant gain in our understanding of what exactly occurs in deep-mixed regimes during active convection periods has been gained through them.

\section{The Gulf of Lions, northwestern Mediterranean}

\subsection{PRECONDITIONING}

It was established that three factors combine to make the Gulf of Lions (Fig.1) a preferred site for deep convection. First, the stratification: The water column is basically three-layered (Fig.2a), with warmer, less saline water of Atlantic origin on top which is separated from the weakly stratified deep layer of Western Mediterranean Deep Water (WMDW) by an intermediate salinity-maximum layer, the Levantine Intermediate Water (LIW) at about $200-500 \mathrm{~m}$ depth. Second, the baroclinic circulation: The near-surface flow is cyclonic, with the LiguroProvencal Current flowing westward along the Cote d'Azur (Millot, 1991), supplied in the east by the East and West Corsican Currents (Astraldi and Gasparini, 1992) and turning into the Catalan Current (Font et al., 1988) that partially continues southward along the Spanish coast
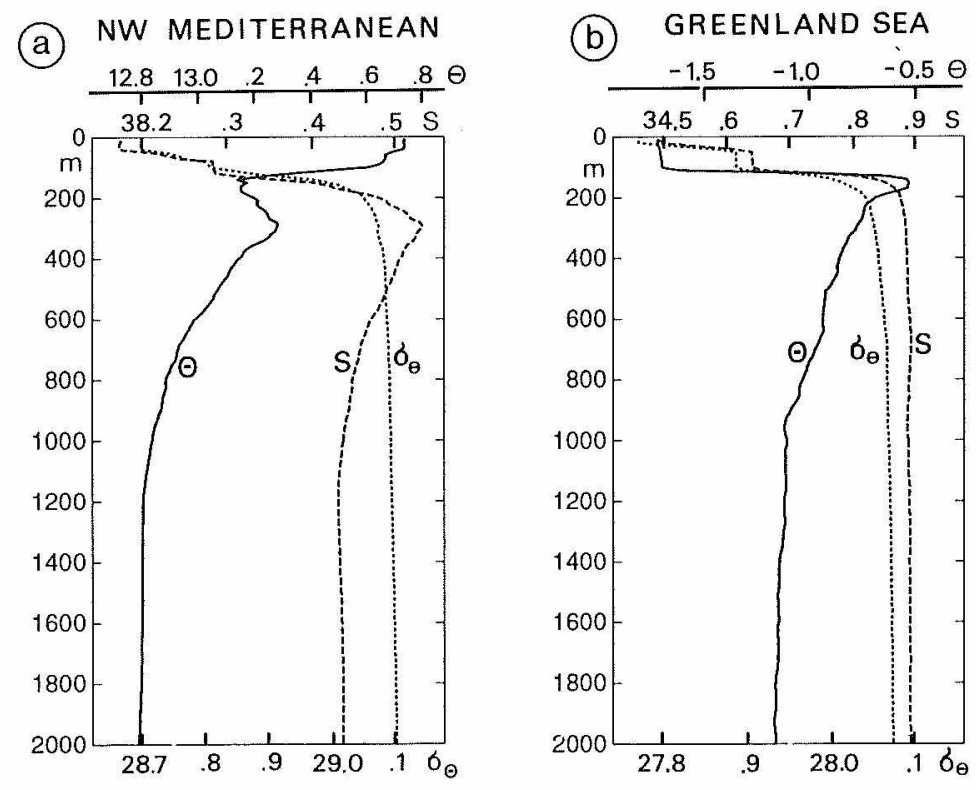

Figure 2: Typical CTD-profiles from preconditioning period

a) center of dome, near 42N,5E, Gulf of Lions, Dec. 1991

b) central Greenland Sea, Nov. 1988 (after GSP group, 1990) 


\section{PRECONDITIONING}

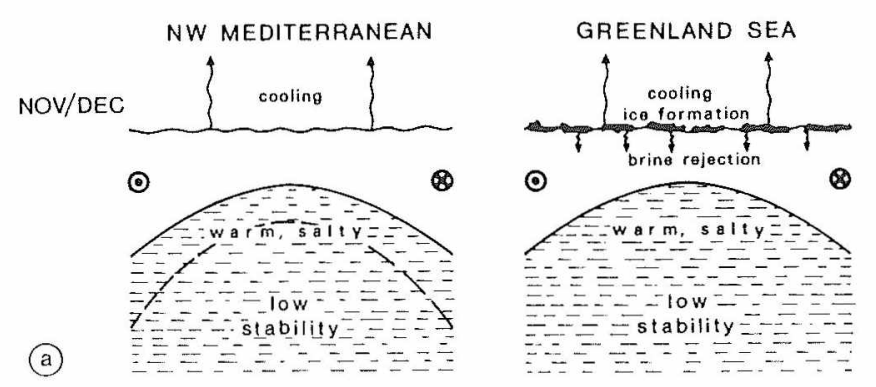

JAN

(b)

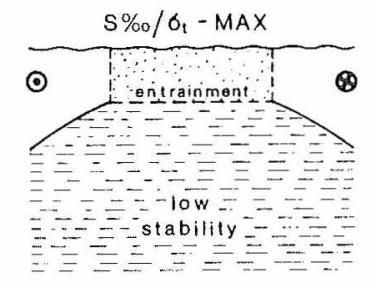

preconditioning pool

FEB

INITIAL CONVECTION

(c)

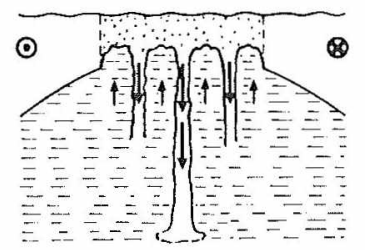

plume

entrainment?

mushrooming?

SCALES IN CONVECTION REGIME

(d)

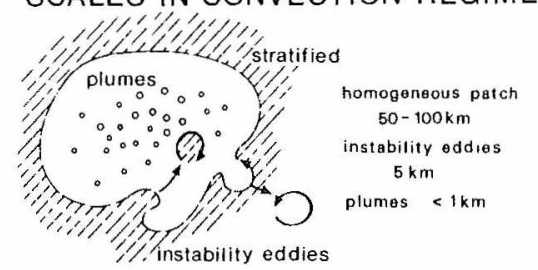

Figure 3: a) Schematic of preconditioning situations during Nov./Dec. in NW Mediterranean (left); and central Greenland Sea (right). Lower layer is saltier and of low stability (e.g., Fig. 2); intermediate $S$ max. of LIW layer in NW Med. marked by dashed line; upper-layer cyclonic circulation indicated; brine rejection important in Greenland Sea for mixed layer salinization in early winter.

b) Development of preconditioning pool in January: combination of density increase and strong winds leads to mixed-layer penetration into the intermediate-water dome; associated with surface salinity and density maximum.

c) Onset of deep convection in February: plumes develop with strong downward motion within and weak compensatory upward motion outside; plumes may broaden on the way down through entrainment of water from the sides; there may also be "mushrooming" when bottom of plumes encounter stratification.

d) The convection regime has three scales : the size of the patch itself $(50-100 \mathrm{~km})$, frontal instability eddies (= Rossby radius of the stratified regime; about $5 \mathrm{~km}$ in NW Med.) and the plume scale of $<1 \mathrm{~km}$. 
and partially recirculates eastward along the southern rim of the Gulf of Lions (Fig.1; as communicated in Erice, partners from Italy, France and Spain now agree to call this northern boundary current the "North Mediterranean Current" rather than switch its name at national borders; C. Millot, pers. communication, 1993).

This cyclonic circulation leads to an uplifting of the isotherms, isohalines and isopycnals in an elongated dome (shown in Fig 1 by the dynamic topography of a Jan. 1969 hydrographic survey). In the center of the dome, the LIW salinity maximum is brought into shallow enough depths to be exposed to mixed-layer entrainment. This is where the third factor comes in, the strong wind outbursts of continental air in winter which cause the maximum of storm activity in the Mediterranean to be located over the northwestern part of the basin. These wind bursts are basically of two types, the Mistral blowing out of the Rhone valley and the Tramontane from out of the Pyrenees. The important aspect for deep convection is that the center of the isopycnal dome lies right in the path of both of these strong winds. These three factors, stratification, circulation and wind, combine over the early parts of winter, November to January, in the so-called preconditioning phase (Swallow and Caston, 1973) to prepare the water column for subsequent deep convection.

The development during the preconditioning phase is schematically shown in Fig.3: During the first part of winter the surface mixed-layer on top of the dome is cooled (Fig.3a). Combined effects of continued cooling and strong winds increase the mixed-layer depth in the later part of winter which leads to entrainment of higher-salinity water out of the LIW layer upwards (Fig.3b). Thus the preconditioning patch can be detected by an associated surface salinity and density maximum. The combined effects of further mixed-layer deepening and cooling decrease stability to the underlying weakly stratified sublayer such that cold air outbreaks in late winter can produce enough buoyancy loss for deep convection (Fig.3c) to set in. A fourth factor that might help by thinning the mixed-layer in the center of the preconditioned patch further through additional doming, could be a Taylor column circulation imposed by the Rhone fan (Fig.1) protruding from the continental slope within the cyclonic dome (Hogg, 1973).

\subsection{DEEP CONVECTION}

a) First evidence of small-scale convection cells

From the earlier Medoc studies, two important horizontal scales were found associated with the convection regime (Fig.3d): that of the deep-mixed patch itself (called "chimney" earlier; Killworth, 1976) and that of the instability eddies that were shed at the front separating the chimney from the stratified surrounding waters. These eddies have the scale of the Rossby radius which for the stratified regime is about $5 \mathrm{~km}$ (Gascard, 1978). In the Gulf of Lions they are apparently originating mostly at the southeastern part of the front.

Recently it has been established, both observationally (Schott and Leaman, 1991; called SL91 in the following) and by modelling (Maxworthy and Narimousa, 1992; Jones and Marshall, 1993), that a third scale is important within an open-ocean convection regime: smallscale cells of typically $<1 \mathrm{~km}$ horizontal scale.

In an experiment with moored acoustic Doppler current profilers (ADCPs), during the winter of early 1987, SL91 documented the presence of shortperiod downward motions in a convection regime that had already previously been homogenized by a strong Mistral during January 1987. The convection region diminished in size during late January to early February and was then opened up again by a second strong Mistral (Figs.4a,b) during 18 25 February with heat fluxes of about $400 \mathrm{Wm}^{-2}$ (Fig4c). It was then that it reached the extent shown in Fig.1 which was much larger than observed either in 1969 or 1992. The downward motions had amplitudes of about $5-10 \mathrm{~cm} \mathrm{~s}^{-1}$ with weaker upward motions of longer duration in between and variances of about $10 \mathrm{~cm}^{2} \mathrm{~s}^{-2}$ during the Mistral period (Fig.4d). From the time scale of advection of these features past the moored station of $<2$ hours and the advection velocity of about $10 \mathrm{~cm} \mathrm{~s}^{-1}$ SL91 concluded that the horizontal scale should be less than $1 \mathrm{~km}$ (Fig.3d). The downward motions began shortly after the onset of the cooling event and decayed quickly when the cooling ended (Figs.4c,d). They were associated with unstable stratification at the top (Fig.4f). During an episode in early February of similarly strong 
(a)

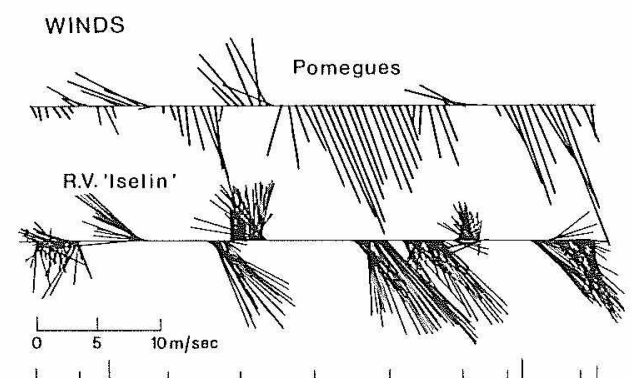

(b)

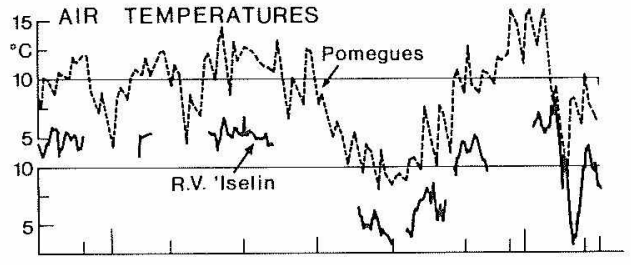

$\underset{W / m^{-2}}{200, \text { HEATFLUX }}$

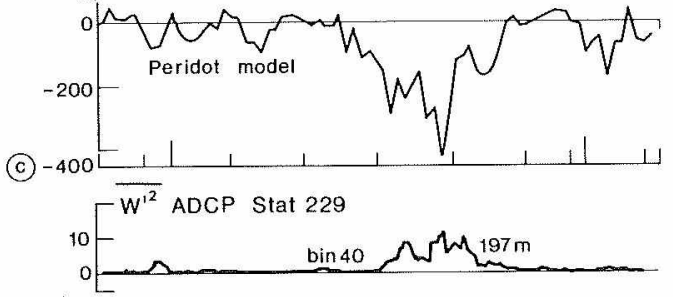

(d)
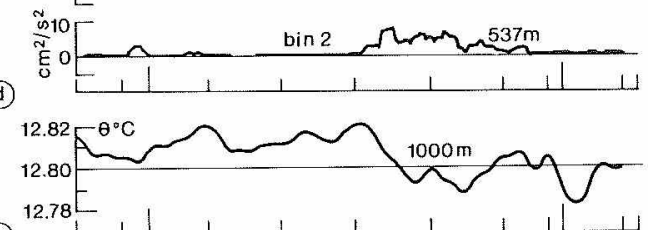

(e)

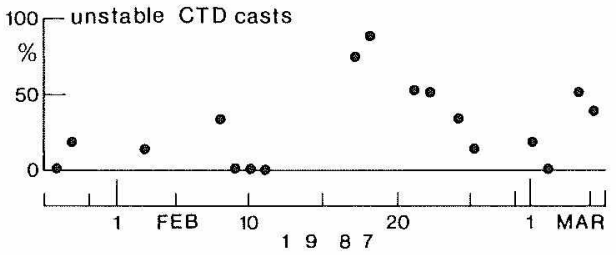

Figure 4: Development of convection in Gulf of Lions in February 1987:

a) Winds and b) air temperatures at coastal station Pomegues and by shipboard recordings near 42N,5E (Fig. 1);

c) Heatflux for $42 N, 5 E$ from Peridot weather prediction model;

d) Vertical velocity variance, indicative of convection activity, at 197, $537 \mathrm{~m}$ depth, from ADCP measurements;

e) potential temperature (smoothed) at $1000 \mathrm{~m}$ depth, averaged from 3 moored stations near 42N,5E:

f) Percentage of daily CTD casts with near-surface inversions. 
winds but without cooling such downward motions were not observed (Figs.4a,c,d). Concerning the small-scale plumes themselves, they were vertically quite homogeneous over the $300 \mathrm{~m}$ observational range of the ADCP. Convincing evidence as to whether they had a preferred sense of rotation could not be established from the Eulerian point measurements.

The integral effect of the plumes within the deep-mixed area was an overall cooling by $0.02^{\circ} \mathrm{C}$ (Fig.4e), in agreement with the surface heat loss over the Mistral period (Leaman and Schott, 1991). The mean vertical velocity over the week was about $1 \mathrm{~cm} \mathrm{~s}^{-1}$ downward. From this result SL91 concluded that a mean downdraft over the convection regime should exist, supporting, in a sense, the earlier "chimney" notion, i.e. that water would be funneled downward within the convection region with a net downward transport and then spread sideways at depth.

\section{b) Plume scales and modelling}

In the short time passed since those first observations significant advancement has been achieved concerning the physics at this newly discovered small scale of convection cells (plumes). Scaling arguments were put forward by Maxworthy and Narimousa (1992) and Jones and Marshall (1993). They are reviewed by Marshall (1993, this issue). In summary, these arguments relate the velocity scale, $U$, and the horizontal scale, $L$, of convective plumes, for times longer than an inertial period after the onset of cooling, to only two outside parameters, surface buoyancy flux, $\mathrm{B}_{0}$, and Coriolis parameter, $\mathrm{f}$. These dependences are

$$
\mathrm{U} \sim\left(\mathrm{B}_{0} / f\right)^{1 / 2} \quad \text { and } \mathrm{L} \sim\left(\mathrm{B}_{0} / \mathfrak{L}^{3}\right)^{1 / 2}
$$

i.e they are only weakly dependent on the buoyancy flux. For a typical heatflux of $500 \mathrm{Wm}^{-2}$ (Fig.4b) the velocity scale would be $5 \mathrm{~cm} \mathrm{~s}^{-1}$ and the length scale $500 \mathrm{~m}$, in approximate agreement with those first small-scale observations.

Hydrostatic numerical models simulating deep convection in the past did so by convective adjustment, i.e. by mixing a gridpoint instantaneously once the density profile got unstable near the top. Such models have been capable of reproducing the salient features of convection regimes reasonably well, i.e. homogeneity, circulation around the margin and instability eddies (e.g., Madec et al., 1991). However, to reproduce plumes requires nonhydrostatic modeling, i.e. inclusion of the acceleration term in the vertical equation of motion. Such modeling at a fairly high resolution of $200 \mathrm{~m}$ horizontally, was carried out by Jones and Marshall (1993), and it did indeed produce plumes underneath a patch of surface cooling that scaled as required by the scaling arguments above.

\subsection{NEW RESULTS FROM WINTER 1991/92}

\section{a) Experimental setup}

A new experiment was carried out in the Gulf of Lions during December 1991 and April 1992 in the context of the EC-MAST/THETIS project (THETIS group, 1993; THETIS stands for "Theoretical and experimental tomography of the sea"). This experiment carried some new ingredients to tackle the different physical components of the convection process. First, a small-scale triangular array of moored stations of $2 \mathrm{~km}$ sidelength (stations A1,A2,T6) that was located in the center of previously observed convection activity (Fig.1). This array carried three downward-looking ADCPs at $350 \mathrm{~m}$ and one station, A1, was additionally equipped with an upward-looking ADCP just above, hence covering the upper $600 \mathrm{~m}$ at vertical intervals of $17 \mathrm{~m}$. Further, A1 was equipped with thermistor strings covering the depth range $50-740 \mathrm{~m}$ for temperature variability. Conductivity was recorded at 4 depths by Seacat recorders, as well, to document salinity variations in conjuntion with deep convection.

The second element of the experiment was a moored array in the boundary current south of Toulon to measure changes in the large-scale cyclonic circulation should they occur in conjunction with the opening of the convection region. Some deep current meters were also deployed at the bottom of the slope to detect potentially occurring larger-scale anticyclonic rotation at depth. The main objective of the experiment was deployment of a tomography 

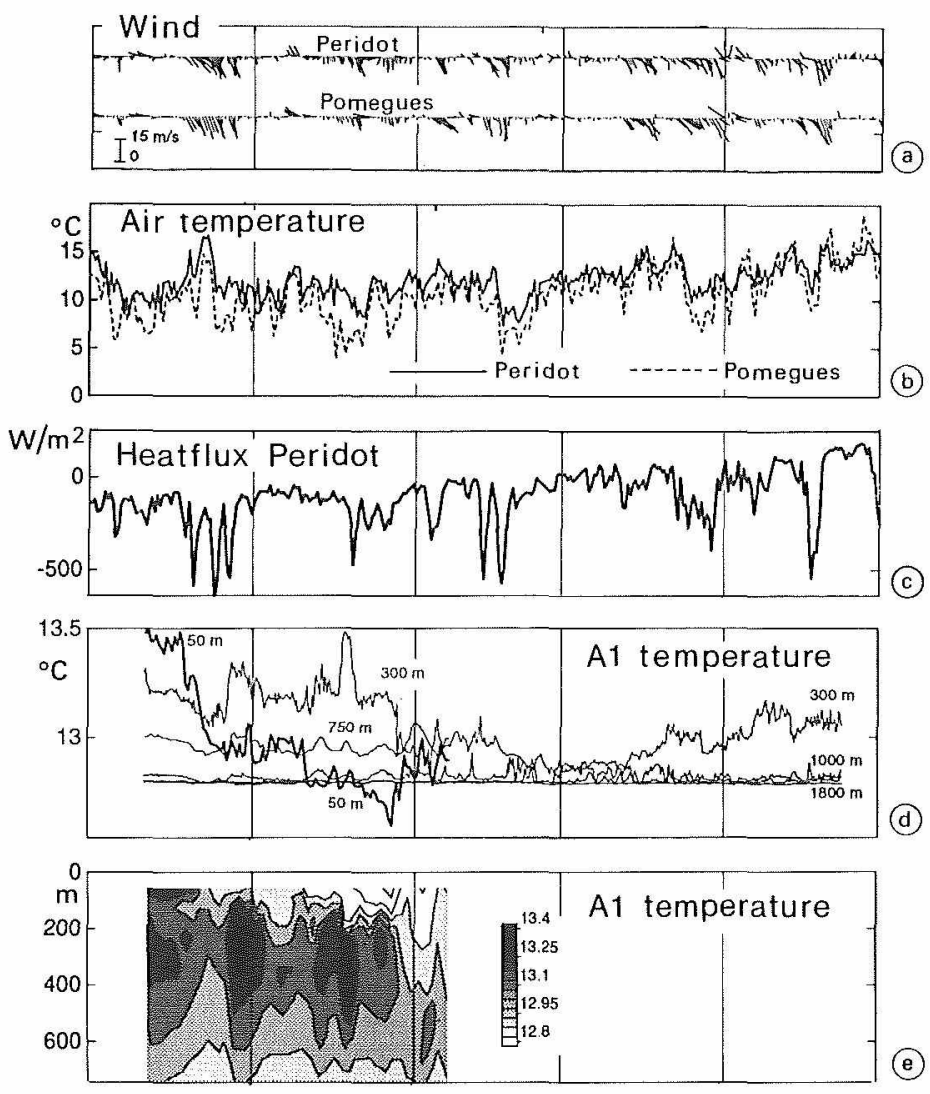

(e)

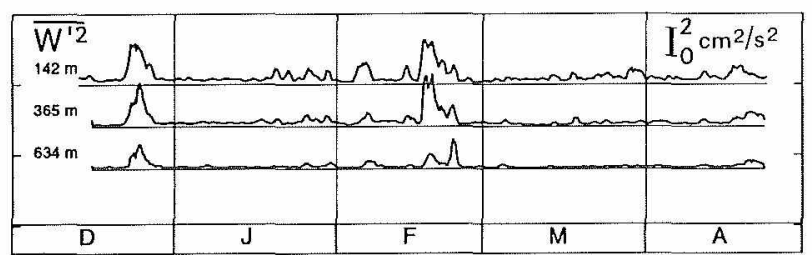

Figure 5: Development of convection in Gulf of Lions in winter 1991/92:

a) Winds (direction towards) and b) air temperatures at Pomegues (Fig.I) and from Peridot model at $42 N, 5 E$;

c) Heatflux from Peridot model at $42 N, 5 E$;

d) Pot. temperature at several depths between $50 \mathrm{~m}$ and $1800 \mathrm{~m}$ at position $\mathrm{Al}$, in small triangle (at 42N,5E; Fig.1);

e) Contour plot of pot. temperature variability in $50-700 \mathrm{~m}$ depth range from thermistor string data at same position as d);

f) Vertical velocity variance at 3 depths, same position as d) 
array, for mapping stratification changes over the convection area on a day to day basis during the winter period. Several ship surveys were carried out, beginning in the preconditioning period of December and running through the period of maximum previous convection activity in February.

b) Forcing and stratification development

A composite picture (Fig.5) shows the development of meteorological conditions, temperature stratification and vertical velocity variance at station A1 (one of the stations in the small triangle near 42N,5E (Fig.1) during the winter period of 1991/92. Wind vectors and air temperatures from coastal station Pomegues (Fig.1) show the development of the Mistrals during the winter period (Figs.5a,b). Also shown are the winds, air temperatures and calculated heat fluxes (Fig. $5 \mathrm{c}$ ) from the Peridot model for a grid point near 42N,5E. The first strong-wind event with cooling of $>500 \mathrm{Wm}^{-2}$ occurred during $17-30$ December 1991, a second one during $20-23$ January. The main event of interest here happend during $18-23$ February 1992, nearly at the same time as in 1987 . From then on, the seasonal warming determined the net heat flux, only briefly interrupted by two late cooling periods, during $20-$ 24 March and, unusually late in the season, $20-24$ April, just before the end of the recording period.

Temperatures from Seacat recorders at 4 depths (Fig.5d) and a contour plot of thermistor string temperatures from depth range $50-740 \mathrm{~m}$ (Fig.5e) at the central position (A1, Fig.1) indicate the mixed-layer cooling and deepening at the first cooling episode in late December, followed again by strengthening of the stratification. In late January, the second cooling phase carried the mixed-layer deepening to $>300 \mathrm{~m}$, eroding the intermediate warm and salty
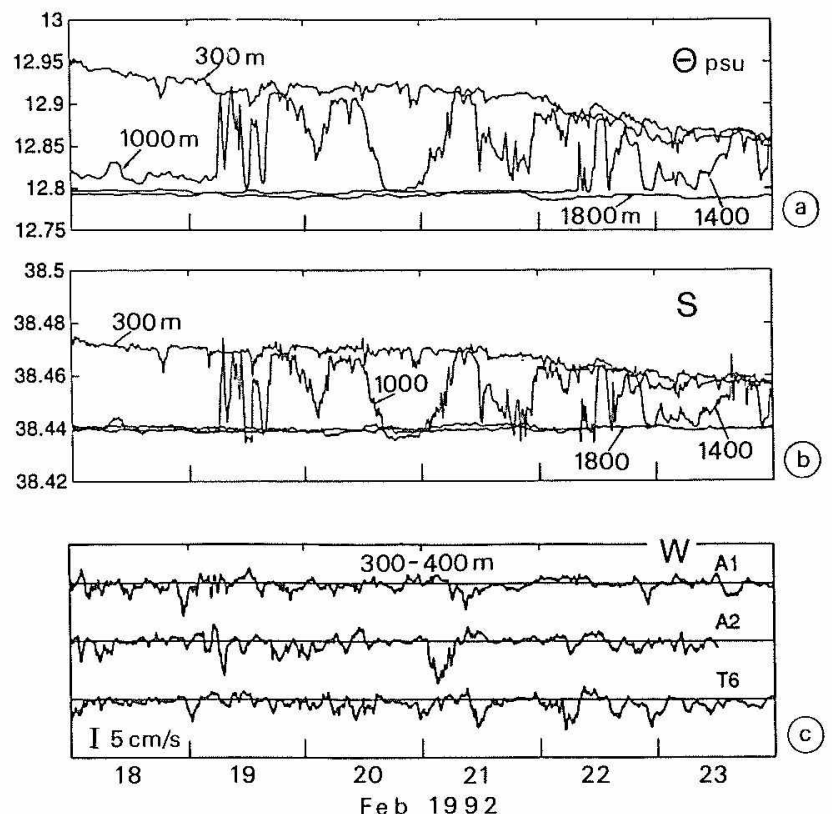

Figure 6: a) Seacat pot. temperatures and b) salinities at $300 \mathrm{~m}, 1000 \mathrm{~m}, 1400 \mathrm{~m}$ and 1800 $m$ at station AI (42N,5E; Fig.l) during February 1992 Mistral;

c) vertical velocities in depth range $300-400 \mathrm{~m}$ at stations A1,A2,T6 of the small-scale triangle ( $2 \mathrm{~km}$ sidelength; near $42 \mathrm{~N}, 5 \mathrm{E} ; \mathrm{Fig.1})$; scale at lower left. 


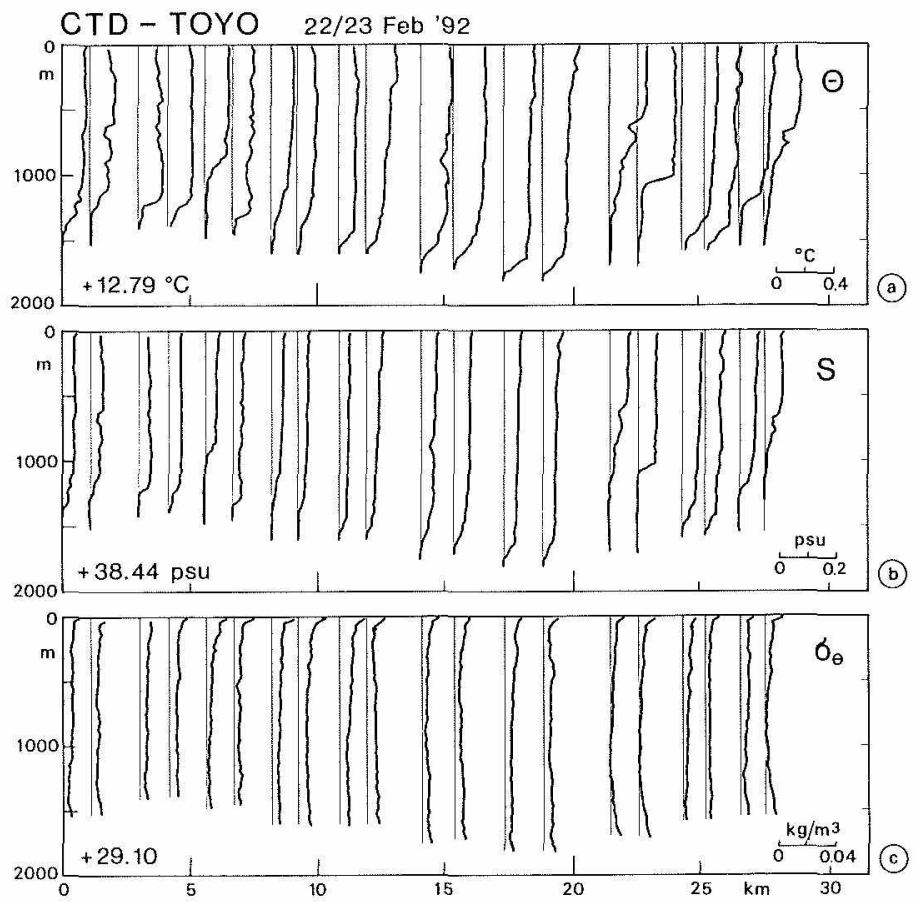

Figure 7: Series of CTD profiles from TOYO-section along 5E, north of $42 N$ (Fig.1): a) pot. temperature (rel. $\left.12.79^{\circ} \mathrm{C}\right)$; b) salinity (rel. $38.44 \mathrm{psu}$ );

c) pot. density (rel. $29.10 \mathrm{~kg} \mathrm{~m}^{3}$ ).

LIW layer. Only in the third phase, after 18 February (when the thermistor string unfortunately had stopped recording) were the sensors at $1000 \mathrm{~m}$ and subsequently also at $1400 \mathrm{~m}$ reached by the homogenization (Figs.6a,b). Yet, by comparison with the 1987 observations the convection was more sporadic and stopped at about $1500 \mathrm{~m}$ depth.

As an example of the remaining inhomogeneities, Fig.7 presents a set of closely spaced profiles of theta,S and sigma-theta, taken by a CTD-TOYO section along $5^{\circ} \mathrm{E}$, from $42^{\circ} 00^{\prime} \mathrm{N}$ to $42^{\circ} 15^{\prime} \mathrm{N}$ within the deep-mixed patch (track marked in Fig.1). The actual path of the CTD through the water was a saw-tooth and profile spacing in Fig.7 is therefore depth dependent. It is obvious that within the region that was deep-mixed in an overall sense, i.e. with its LIW T,S-maxima destroyed, significant water mass differences remained over horizontal separations of only about $1 \mathrm{~km}$. It is noteworthy that the step-like structures in temperature and salinity are to a great extent compensated in density (Fig.7c), i.e. the convection had been non-penetrative. During the time of the section, which was carried out at night on 24/25 February aboard $\mathrm{R} / \mathrm{V}^{\prime \prime}$ Poseidon" cooling was going on at about $400 \mathrm{Wm}^{-2}$, and near-surface density was mostly unstably stratified, as already discussed for the 1987 survey by Leaman and Schott (1991).

\section{c) Vertical velocities}

Pronounced bursts of vertical velocity variance, exceeding $5 \mathrm{~cm}^{2} \mathrm{~s}^{-2}$, occurred in conjunction with the strong wind events of late December and mid-February, weaker variance maxima were observed in late January, $6-8$ February and late April (Fig.5f). The period of 
maximum interest is $18-23$ February, when convection was ongoing. The December peak occurred while stratification below the surface-mixed layer was still in existence (Fig.5e). That variance is due to internal waves that were generated by momentum transfer from mixedlayer turbulence to the stratified interfacial layer (Visbeck, 1993). Vertical velocities for the $300-400 \mathrm{~m}$ depth range from the three positions of the triangle ( $2 \mathrm{~km}$ side-length; inset in Fig.1) are shown in Fig.6c together with the Seacat temperature and salinity recordings (Figs.6a,b). Downward velocities reach about $10 \mathrm{~cm} \mathrm{~s}^{-1}$ and do not occur in any obviously related way among the three positions; hence, clearly the horizontal scale of the individual convection events is less than the $2 \mathrm{~km}$ mooring separation. Considering the downward events as frozen structures of typically $2-4$ hours duration that are advected past the moored position by the mean currents of typically $5-10 \mathrm{~cm} \mathrm{~s}^{-1}$ yields scales of the cells in the range of $200-1000 \mathrm{~m}$, in agreement with the observed horizontal decorrelation among the moorings. An important result of this new experiment are the vertical mean currents from the four ADCPs, deployed at positions A1 (with 2 instruments measuring upwards and downwards from $350 \mathrm{~m}$ ), and from A2 and T6, measuring downwards from $350 \mathrm{~m}$ depth (Table 1). While there is some scatter and the difference between the vertically closely spaced instruments on position A1 testifies to the still remaining accuracy problems of the ADCPs, all 4 means are only slightly different from zero, supporting the result that plumes are not funneling water downward in a significant mean vertical motion but rather act as mixing agents, in agreement with scaling arguments and numerical model results (Jones and Marshall, 1993; Send and Marshall, 1993). We will come back to this point at the end.

TABLE 1. Peak values, means and variances of vertical velocities measured by moored ADCPS in three convection experiments

\begin{tabular}{|c|c|c|c|c|c|c|c|}
\hline area & $\begin{array}{l}\text { time } \\
\text { period }\end{array}$ & $\begin{array}{l}\text { station and } \\
\text { instr. ID }\end{array}$ & $\mathrm{d} \begin{array}{c}\text { ADCP } \\
\text { depth } \\
\text { range } \\
(\mathrm{m})\end{array}$ & $\begin{array}{r}\max * \\
\text { dou } \\
\text { (c) }\end{array}$ & $\begin{array}{l}\text { mean*) } \\
\text { ard } \\
-1)\end{array}$ & $\begin{array}{l}\text { variance*) } \\
\left(\mathrm{cm}^{2} \mathrm{~s}^{-2}\right)\end{array}$ & mixing \\
\hline $\begin{array}{l}\text { Gulf of } \\
\text { Lions }\end{array}$ & $\begin{array}{l}15-22 \text { Feb. } \\
1987\end{array}$ & 229 & $450-550$ & 12 & -1.0 & 10.9 & complete \\
\hline $\begin{array}{l}\text { Greenl. } \\
\text { Sea }\end{array}$ & $\begin{array}{l}6-16 \text { Mar. } \\
1989\end{array}$ & $\begin{array}{l}319 \\
\text { T6U } \\
\text { T6L }\end{array}$ & $\begin{array}{r}230-320 \\
200-300 \\
1300-1400\end{array}$ & $\begin{array}{l}2 \\
3 \\
3\end{array}$ & $\begin{array}{l}0.0 \\
0.1 \\
0.0\end{array}$ & $\begin{array}{l}1.0 \\
1.7 \\
0.6\end{array}$ & incomplete \\
\hline $\begin{array}{l}\text { Gulf of } \\
\text { Lions }\end{array}$ & $\begin{array}{l}18-23 \mathrm{Feb} . \\
1987\end{array}$ & $\begin{array}{l}\text { A1UP } \\
\text { A1DO } \\
\text { A2 } \\
\text { T6 }\end{array}$ & $\begin{array}{ll}190- & 280 \\
350- & 425 \\
330- & 400 \\
330- & 380\end{array}$ & $\begin{array}{l}6 \\
7 \\
8 \\
8\end{array}$ & $\begin{array}{r}0.1 \\
0.0 \\
-0.2 \\
-0.6\end{array}$ & $\begin{array}{l}4.2 \\
2.9 \\
5.3 \\
3.9\end{array}$ & incomplete \\
\hline
\end{tabular}

*) vertical velocities were corrected for zooplankton migration

Another significant difference of the 1992 experiment compared to the 1987 results was the observation that the mixing within the convection regime remained incomplete, i.e., significant horizontal water mass differences remained as discussed in conjunction with Fig.7. In this respect there was a similarity to the 1969 Medoc hydrographic measurements that also showed individual mixed volumes within stratified environment (Sankey, 1973; Swallow and Caston, 1973). In both years, 1992 and 1969, the depth range of the convection did not reach the bottom. In 1987 the mixing reached the bottom, horizontal water mass differences within the patch were minimal (Leaman and Schott, 1991), and the maximum extent of the deepmixed regime (Fig.1) was several times larger than that of the other two years. Hence, 1987 
was probably as much an exception for convection in the Gulf of Lions as the 1982/83 El Nino was for Pacific ENSO events.

Different from the 1987 experiment that only started ADCP recording in late January, the 1991/92 experiment covered all phases of the preconditioning and convection period. There it is noteworthy that the phase in late January when the Levantine Intermediate Water layer was broken through by the convection is not particularly distinguishable in the vertical velocity variances. This was in the earlier definitions of convection stages called the phase of "violent mixing", but according to these observations it is not anymore violent than other cooling phases of that winter period.

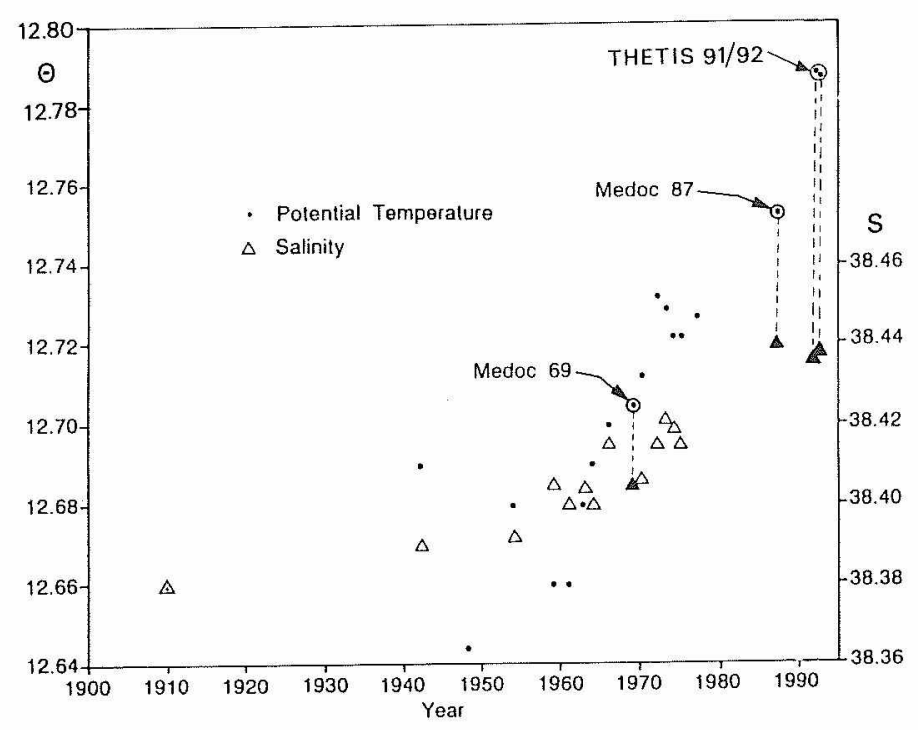

Figure 8: Increases of Deep Water temperatures and salinities in the NW Mediterranean over past decades (Leaman and Schott, 1991; continued until 1992); data pairs of the experiments in 1969, 1987 and 1991/92 are connected. THETIS data are averages over 1800 - $2000 \mathrm{~m}$ depth range from December, 1991 and February, 1992.

\subsection{DEEP-WATER PROPERTIES: SEASONAL, INTERANNUAL AND LONG-TERM CHANGES}

While the Deep Water in the 1987 study was well mixed, though with small gradients allowing the identification of individual water bodies that were within themselves even more homogeneous, the situation in 1992 was clearly different: significant horizontal gradients remained and the mixing was incomplete. The result was increased variance of deep temperatures after the convection period against the pre-mixing variance - most notable at the $1400 \mathrm{~m}$ sensor, only slightly above the maximum convection depth observed. This deep variance remains for some time after the occurrence of the convection thus providing a "tracer" for convection that took place even if measurements are not directly within the convection area or when measurements can only be conducted after the convection period. 
If the water in the convection region is not funneled down but only mixed in place within the confines of the patch and then released into the deep environment through sinking, spindown, or interaction with the stratified surroundings, what would this mean for the volume of water mass modification? Mixing a cylindrical volume of $50 \mathrm{~km}$ radius and $2 \mathrm{~km}$ depth will generate a volume of $1.5^{*} 10^{13} \mathrm{~m}^{3}$. Assuming this occurs once per year corresponds to an annual mean production rate of about $0.4 * 10^{6} \mathrm{~m}^{3} \mathrm{~s}^{-1}$, about the rate of Western Mediterranean Deep Water (WMDW) that is assumed to participate in the Gibraltar Straits outflow (Bryden and Kinder, 1991). Hence, mixing a reasonably sized volume by comparison with observed patch sizes (Fig.1) will yield enough WMDW and funneling down is not required (Send and Marshall, 1993).

The T,S properties of newly generated WMDW have been observed to show interannual variations that appear to be related to anomalies in the local atmosphere-ocean exchange. For example, Prieur et al. (1983) found higher WMDW salinities after an extended drought spell during 1981 that lead to increased surface salinity in the following winter and an extended convection period. Bethoux (1993, this issue) has extended this search for interelations between precipitation anomalies and WMDW TS-anomalies and describes some evidence as to their existence.

Overall, the deep water properties of the northwestern Mediterranean have changed significantly over the past decades with WMDW temperature increasing by $0.05{ }^{\circ} \mathrm{C}$ during $1969-1987$ and salinity by 0.035 psu (Fig.8). The latest measurements from the THETIS project from winter 1991/92, presented for profile means in the depth range $1800-2000 \mathrm{~m}$ during a survey in early December and in mid-February are included. The temperature shows an accelerated increase against the $1969-87$ rate by yet another $0.035^{\circ} \mathrm{C}$ while, interestingly enough, salinity did not increase further during $1987-92$. The longterm trend has been either attributed to global warming (Bethoux et al., 1990) or to the influence of man-made decreased freshwater influx into the eastern Mediterranean (Leaman and Schott, 1991; Rohling and Bryden, 1992). The explanation there is that the increased salinity of the LIW entering the western basin through the Straits of Sicily will enable convection to occur at higher than previous temperatures.

\subsection{POSSIBLE RELATIONS OF COOLING AND CONVECTION TO LARGE-SCALE FLOW}

The cyclonic circulation and doming in the northwestern Mediterranean, as described above, is a very solid feature, that appears to have a seasonal transport maximum in winter (e.g. Bethoux et al., 1988). It has been suggested that this seasonal maximum is related to the watermass modification by winter convection in the northwestern Mediterranean (Astraldi and Gasparini, 1992). There are, however, three possible reasons for this cyclonic transport enhancement in winter. First, the distribution of windstress. The annual mean is characterized by cyclonic curl over the northwestern Mediterranean; and the seasonal cycle shows a maximum cyclonic curl in winter. Correspondingly, numerical models that are purely winddriven (e.g., Heburn, 1987), show a cyclonic circulation around the margin of the western basin with a strong maximum in January. The second cause for enhanced cyclonic circulation in winter is coastal fresh water discharge, which establishes an offshore density gradient and corresponding alongshore current (Bethoux et al., 1985). The third cause is the thermohaline forcing itself. Cooling over an area of the Gulf of Lions will also establish a horizontal density gradient favoring cyclonic circulation. Evidence supporting such relation was shown by Astraldi and Gasparini (1992), based on transport measurements by moored current meter stations east and west of Corsica. In the three winters during late 1985 to early 1988 they recorded decreasing mean winter transports and correspondingly they found decreasing mean winter heat fluxes over the northwestern basin using coarse estimations based on meteorological station data from Cap Bear. Further, during the winter of 1987/88 two successive maxima in transport were recorded, each occurring about two weeks after very pronounced spikes in heat loss. Such transport enhancement does not necessarily have to be related to deep convection; in fact, as we will see below, the circulation immediately around a convection regime is apparently limited to a very narrow rim and most likely not linked to the large-scale circulation around the basin. It could be that the relation between transport and 
cooling just reflects the increased horizontal density and pressure gradients caused by the cooled preconditioning patch in the center of the Gulf of Lions and that it also occurs if no deep convection results at all in a particular winter.

In summary there is a complex relation between the annual cycle of the alongshore circulation in the northwestern basin and three potential causes, windstress, freshwater discharge and surface heatflux. The freshwater discharge has its seasonal maximum somewhat later than the winter storm and cooling intensity which should help in delineating the different effects. Whether there is a significant relation between the alongshore flow and deep convection is still an open question.

\section{Greenland Sea convection and the role of ice}

\subsection{CIRCULATION AND PRECONDITIONING}

The circulation system of the Greenland Sea is characterized by cyclonic upper-layer flow (Fig.9). In the east relatively warm and saline water is carried northward by the NorwegianAtlantic Current that branches into the Barents Sea and the West Spitsbergen Current north of Norway. One branch of it curls cyclonically around the Greenland Sea, thus providing an essential input of salt into the convection region. North of the Greenland Sea gyre a second gyre is sometimes found in the Boreas Basin (Fig.9) In the west, the East Greenland Current carries cold and low-salinity Polar Water southward. One branch of it, the Jan Mayen Current, turns toward the east along about $72^{\circ} \mathrm{N}$. This input of low-salinity surface water into the southern Greenland Sea is an important ingredient in ice production and convection supression. The result of the cyclonic circulation is pronounced doming of the isotherms, isohalines and isopycnals over the central Greenland Sea, as indicated in Fig.9 by the topography of the $0^{\circ} \mathrm{C}$ isotherm for the Greenland and Boreas basins. We thus find again the classical preconditioning situation as described before for the NW Mediterranean: a strong cyclonic dome with colder fresher water overlying saltier water, except that a subsurface salinity maximum does not occur (Fig.2b). The third ingredient needed for convection are strong winds with significant water vapor and temperature deficits against the local environment. This is provided when the ice cover in winter extends from Greenland toward the Greenland Sea (Fig.1) and winds with westerly components will be cold and dry.

The difference to the Mediterranean now is the role of the ice. While convection in the Gulf of Lions is a fairly regular process, evidence for convection is much sparser in the Greenland Sea and the ice may contribute in an enhancing or inhibiting way to the process.

The ice has a peculiar seasonal development over the Greenland Sea. In late November the ice edge, spreading eastward from Greenland passes over the central Greenland Sea; in late December the ice reaches its greatest eastward extent and in mid-January a so-far not well understood phenomenon begins to unfold: beginning in the north, a large bay of ice-free water opens up over the central Greenland Sea (called "nordbukta"; Vinje, 1977), around which a wedge of ice is wrapped from the southwest over the Jan Mayen Current to the northeast (the "Is Odden"). The Is Odden thus basically resides over the low saline Polar Water spreading eastward out of the East Greenland Current. The extent of the Is Odden in early March 1989, when convection was observed in the central Greenland Sea, is marked in Fig.9.

The sequence of preconditioning and onset of convection in the Greenland Sea (GS) is as follows:

Oct.-Nov.: • First cooling events;

late Nov.: - Ice edge passes eastward over central GS;

Dec-Jan: - Mixed-layer (ML) under the ice cools to freezing point $\left(-1.9^{\circ} \mathrm{C}\right)$ and deepens by by about $1 \mathrm{~m} /$ day (as shown in Fig. 10 for temperature distribution at stat. M319, in the western central GS);

- salinization by brine rejection (Fig.3a,r.h.s.)

late Jan.: - Opening of ice-free bay in central GS ("nord bukta") leaving wedge of ice around central GS ; 
Feb.: - through wind mixing the exposed ML of much decreased stability against the weakly stratified sublayer now deepens drastically to up to $400 \mathrm{~m}$ (Fig.10), while warm water is mixed upwards through entrainment (Fig.3b);

- the warmer, more saline water is cooled further until a pool of well-mixed preconditioned water of a scale of about $50-100 \mathrm{~km}$ (in 1989) is created in the central Greenland Sea out of which convection will begin subsequently;

March: • convection may occur out of preconditioned pool upon favourable meteorological conditions.

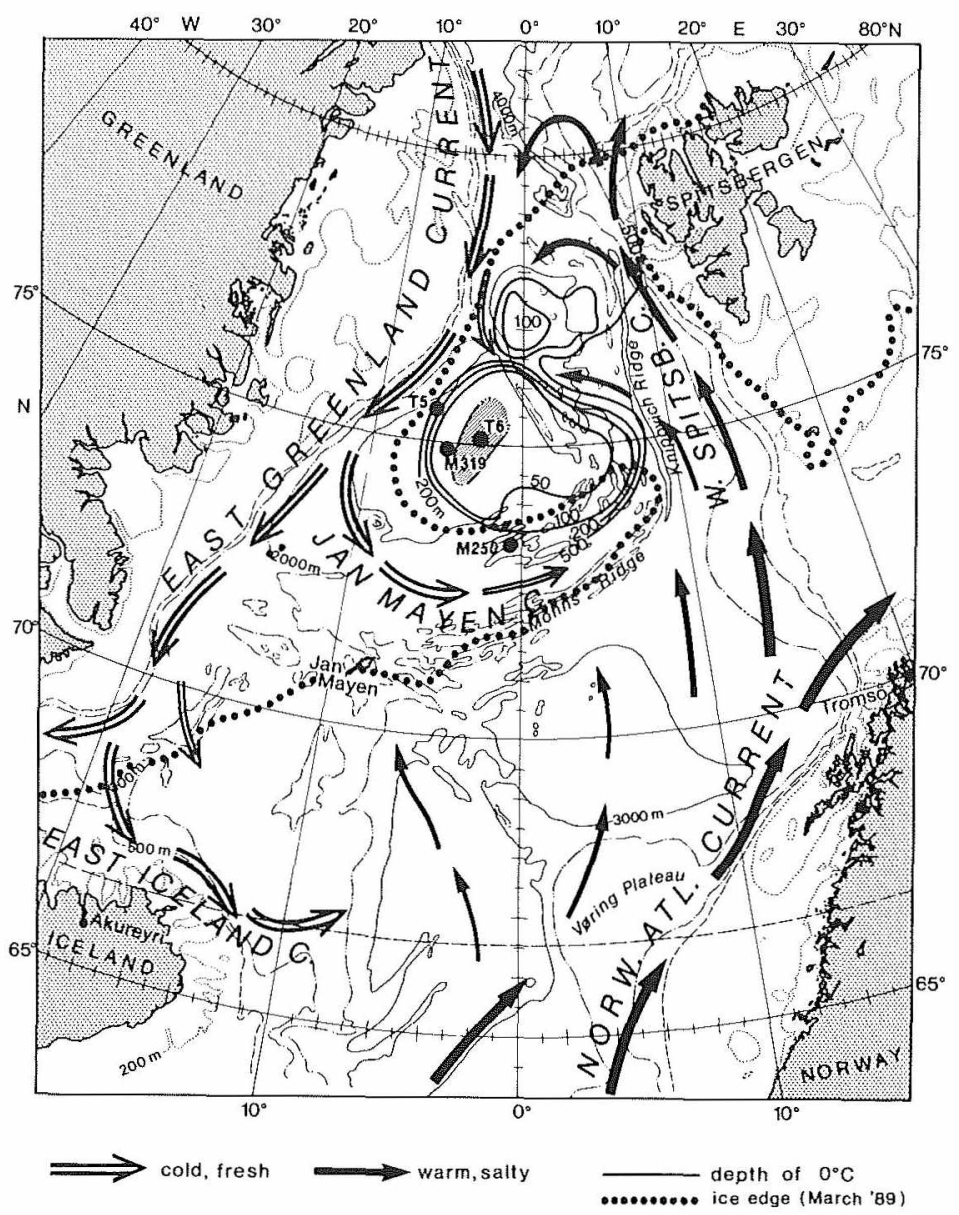

Figure 9: Circulation of warm/saline waters from Norwegian-Atlantic Current and cold/fresh waters from East Greenland Current in Greenland and Norwegian Sea. Doming in Greenland and Boreas basins indicated by $0^{\circ} \mathrm{C}$ isotherm topography (from Quadfasel and Meinke, 1987); ice edge for March 1989 and ADCP positions of GSP experiment 1988/89 are marked. Hatched area is preconditioned pool in March 1989 (from Johannessen and Sandven, 1989). 


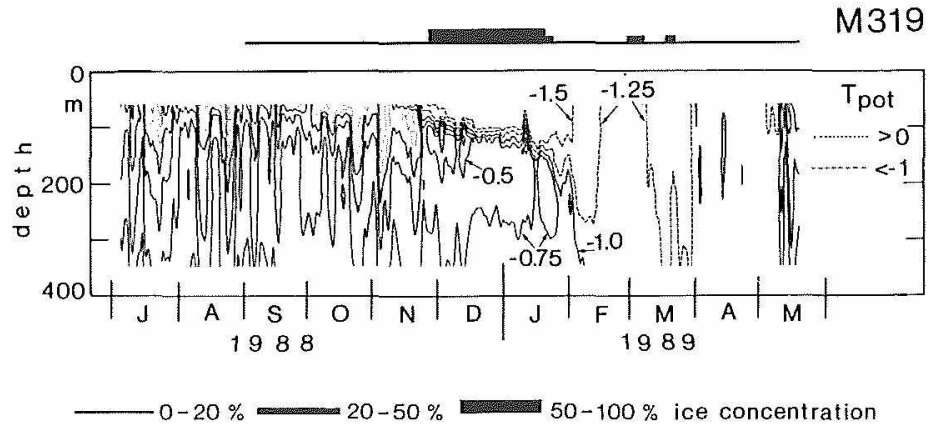

Figure 10: Temperature stratification in depth range $60-370 \mathrm{~m}$ at pos. M319 (Fig.9) in central Greenland Sea during winter 1988/89. Ice concentration over station marked by bar graphs.

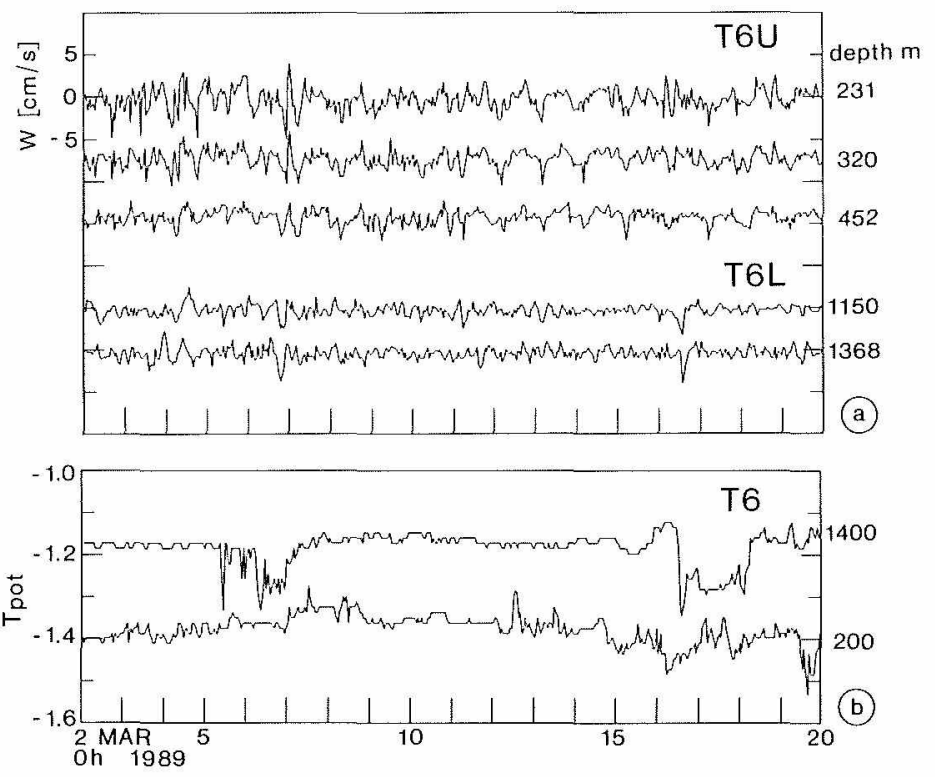

Figure 11: a) Vertical ADCP currents at different depths at position T6 during 2-20 March 1989; note deep convection events on 6 and 16 March;

b) Potential temperatures at $200 \mathrm{~m}$ and $1400 \mathrm{~m}$ depth.

An important part is that brine rejection by the ice is an ingredient of preconditioning but not the trigger of the subsequent deep convection. Recent salinity measurements in the mixed layer under the ice (Roach et al., 1993) show the salinization at freezing point temperatures in 
Nov. - Jan. that diminishes the density gradient. The homogeneous pool in March 1989 was documented by Johannessen and Sandven (1989). The great puzzle still is how the ice-free bay can open up so quickly. If it was meltback by upwelling of warm water from the sublayer, the stability would be increased again making convection impossible. As Visbeck (1993) has shown in a mixed layer model calculation with ice consideration, an ice export out of the area is needed to explain this phenomenon. Ice tracking by upward-looking ADCPs on stations M250 and M319 (Fig.9) seems support this conclusion.
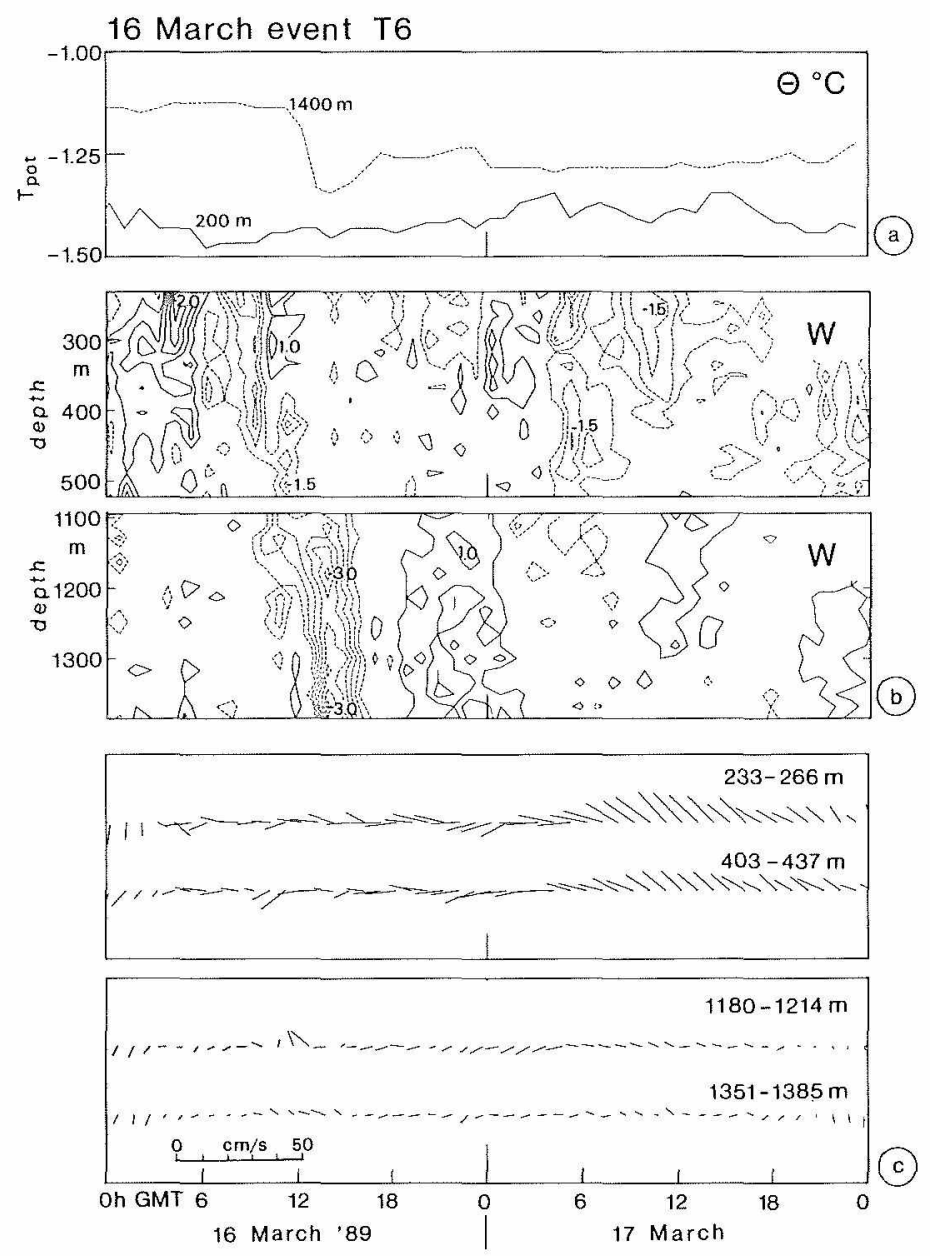

Figure 12: Convection event of 16 March:

a) Pot. Temperatures; b) Vertical velocities at $250-510 \mathrm{~m}$ and $1100-1370 \mathrm{~m}$ depth (contour interval $0.5 \mathrm{~cm} \mathrm{~s}^{-1}$ ), suggesting slanted plume;

c) horizontal current vectors for different depth ranges, suggesting cyclonic rotation at shallow and anticyclonic rotation at deeper depth levels (from Schott et al., 1993). 


\subsection{VERTICAL VELOCITIES AND CONVECTION}

Measurements with moored ADCPs on the positions marked in Fig.9 were carried out over the winter of $1988 / 89$ (Schott et al., 1993). Strong vertical current fluctuations in the thermocline were first observed with strong-wind and cooling events in November, but these were internal waves caused by mixed-layer turbulence during the cooling phases as shown by Visbeck (1993) who applied internal wave consistency tests to the ADCP measurements. Nothing happened underneath the ice in Nov. - Dec., but with the onset of mixed-1ayer deepening in February increased vertical velocity variance within the mixed layer was recorded. Deep convection was only recorded in the first half of March when the preconditioned pool was in place. Fig 11 shows vertical velocity fluctuations recorded by an upper (T6U) and a lower (T6L) ADCP at the central station T6 during $2-20 \mathrm{March}$, and noteworthy are shortperiod downward motions at the deep levels on 6 and 16 March. Deep temperatures at these times also decrease but not to the low temperature of the near-surface pool which might suggest entrainment of plumes on the way down.

An expanded view of the 16 March event is shown in Fig.12. Horizontal currents at the time of that event were westward and stronger in the upper layer (Fig.12c). The contour diagram of the vertical velocities over the observational range of both ADCPs (Fig.12b) suggests that the plume is arriving earlier at the top than at the bottom, in agreement with the baroclinic horizontal currents; it means that the plume is slanted westward. The horizontal current variations during the passage are in agreement with cyclonic rotation of the plume in the upper and anticyclonic rotation in the lower layer.

CTD profiles in the vicinity found individual deep-mixed (to $1500 \mathrm{~m}$ ) stations (GSP group, 1990; Rhein, 1991) within stratification, similar to what was observed 1992 in the Gulf of Lions, i.e. a case of incomplete mixing again.

\section{Summary and conclusions}

Convection research has made considerable progress in the past few years. In this paper, results from recent observations from the Gulf of Lions, northwestern Mediterranean and from the central Greenland Sea have been summarized that focussed on the processes within deep-mixed regimes when active convection was underway.

For the Greenland Sea some new insights have also been gained into the conditions that need to be met in order for deep convection to occur in the first place. The preconditioning there leading up to convection requires the formation of ice in early winter and associated brine rejection to increase mixed-layer salinity at freezing point temperatures over the course of winter and reduce stability to underlying weakly stratified waters. In the later part of winter, strong surface winds generate ice export and cause mixed-layer deepening, entraining warmer, saltier water up from underneath that is cooled further, generating a pool of dense water in the central Greenland Sea several $100 \mathrm{~m}$ deep and $\mathrm{o}(100 \mathrm{~km})$ wide. Out of this icefree pool convection begins to develop in late winter. Ice edge upwelling that was sometimes proposed as an important mechanism to bring warm salty water up does not appear to be of such importance for the process. The role of the ice is important in the preconditionig phase (November-February) rather than for deep convection itself (March). This conclusion from the 1988/89 measurements is supported by temperature records from the subsequent winter from near pos. T6 (Fig.9) that gave no indication of the development of a preconditioned pool (as seen for early 1989 in the homogeneous temperature distribution for Feb. 1989 in Fig.10) and of subsequent convection; and the reason apparently was a different and generally weaker ice cover in early 1990 compared to early 1989.

The new observations within convection regimes by acoustic Doppler current profilers proved the existence of small-scale convection cells with horizontal scales of only a few $100 \mathrm{~m}$. What are the common features of these phenomena? Some statistics are put together in Table 1. 
Concerning the mean vertical motion within a convection regime, an important result of the two experiments with several simultaneously deployed ADCPs, Greenland Sea 1989 and Gulf of Lions 1992, is that mean vertical currents during a convection period are small. In 1987 the single ADCP yielded a mean downward motion of $-1 \mathrm{~cm} \mathrm{~s}^{-1}$ over the Mistral period. This lead SL91 to conclude that the convection regime was in fact funneling water downward in a mean transport mode. Vorticity constraints, however, prohibit this from happening on the scale of tens of kilometers, implying that convection cells rather act as mixing agents with negligible mean vertical transport as discussed by Send and Marshall (1993). They analyzed the nonhydrostatic model results of Jones and Marshall (1993), where mean vertical transport only occurs by adjustment of the margins of the convection regime within the scale of a Rossby radius. The overall mean vertical velocity when averaged horizontally over the model convection patch, is only $0.1 \mathrm{~cm} \mathrm{~s}^{-1}$ during the geostrophic adjustment phase.

From the linear vorticity balance, a relation between patch-mean downward motion w and rim current $U$ results that is approximately

$$
\mathrm{U} \sim \mathrm{fTwr} / 2 \mathrm{H}
$$

with $\mathrm{r}$ radius of convection patch, $\mathrm{H}$ its depth and $\mathrm{T}$ timescale. For $\mathrm{T}=1$ week, $\mathrm{r}=50 \mathrm{~km}$, and $\mathrm{U}<0.5 \mathrm{~m} \mathrm{~s}^{-1}$ a vertical mean velocity of $\mathrm{w}<0.1 \mathrm{~cm} \mathrm{~s}^{-1}$ follows.

Near-zero vertical mean currents are in agreement with the more recent experimental results: In the THETIS experiment 1992 the average over the 4 mean values during $18-23$ Feb. was only $-0.2 \mathrm{~cm} \mathrm{~s}^{-1}$ (Table 1). Similarly, in the Greenland Sea, the means at positions T6, both in the depth range $200-300 \mathrm{~m}$ and $1300-1400 \mathrm{~m}$ (Table 1) were close to zero. These results support the notion that convection cells (plumes) act like a mixing agent, as sketched schematically in Fig.3c. They exchange water mass properties vertically but with only small vertical net volume transport involved.

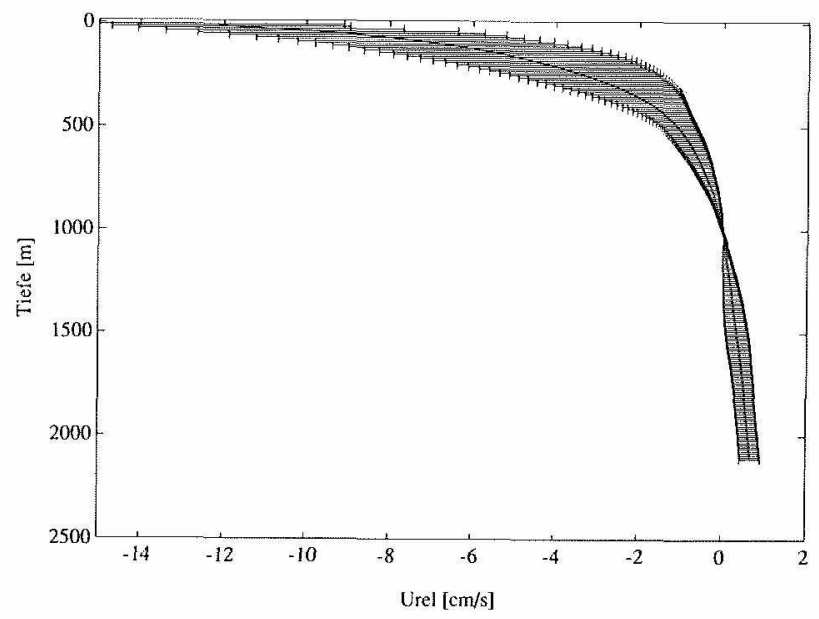

Figure 13: Rim current across Gulf of Lions convection patch, determined from averaging geostrophic shears from various station pairs (rel. 1000 dbar) across the patch margin (Fig.1). 
The rim current for the THETIS experiment is shown in Fig.13, as determined from geostrophic shears (rel. 1000 dbar) between CTD stations across the margin (marked in Fig.1). It has a maximum of only about $15 \mathrm{~cm} \mathrm{~s}^{-1}$ at the surface, in agreement with above arguments. Also, as derived from scaling and modelling, it was confined closely to the boundary of the patch and not apparently coupled to the larger-scale boundary circulation, although that needs further analysis. That suggests that the relations between cooling and boundary flow observed by Astraldi and Gasparini (1992) might be caused by the larger-scale density gradients due to general mixed-layer density increase in the Gulf of Lions rather than by the convection patch with its separate circulation.

As regards the low patch-averaged mean vertical motions, there are, however, structural differences within a model patch: closer inspection shows (Send and Marshall, 1993) that mean vertical flow occurs only near the rim. Time-averaging vertical currents near the rim inside the model convection patch yields downward means more near $1 \mathrm{~cm} \mathrm{~s}^{-1}$. Hence there are conditions where a significant mean downward flow at a position as recorded by SL91 could be realistic. Another possibility, as pointed out by Visbeck (1993), could be that the 1987 measurements were taken while a cyclonic eddy of about $5 \mathrm{~km}$ radius was slowly drifting by (the horizontal current vectors in SL91 suggest that). In that case, $w$ in above formula can come up to about $1 \mathrm{~cm} \mathrm{~s}^{-1}$.
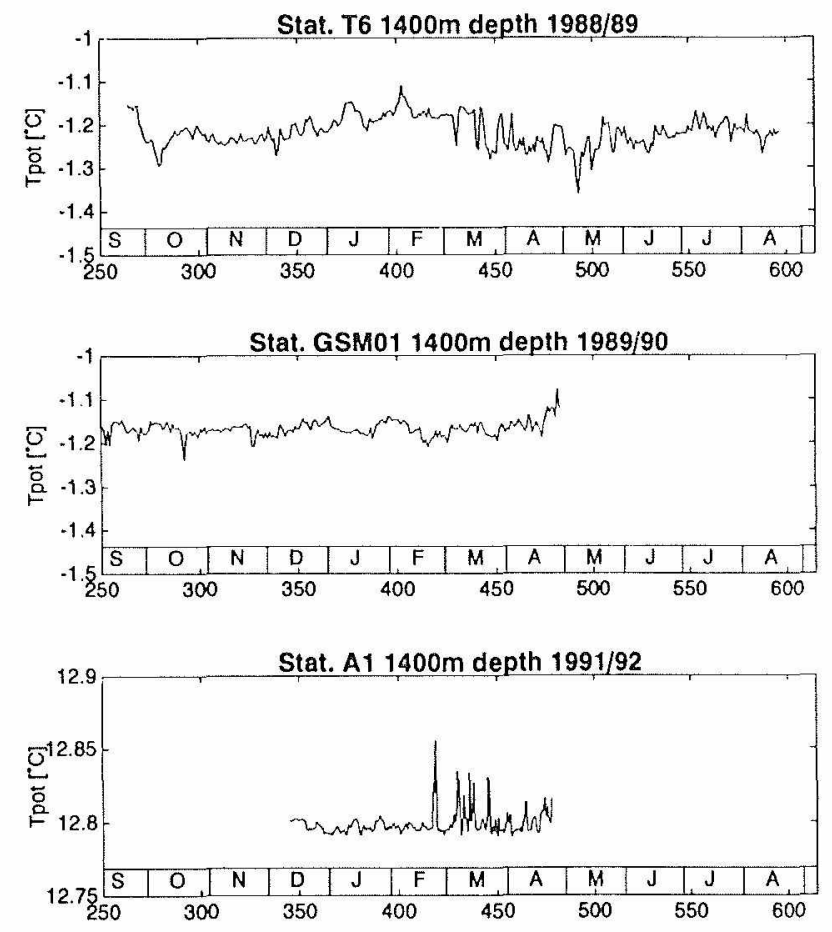

Figure 14: Deep temperature variability in the Greenland Sea for winter 1988/1990; indicating convection activity in winter 1988/89 but not 1989/90.

There is also another difference between the 1987 result and the two subsequent experiments which may or may not be relevant for the significant mean vertical current in 1987 but not the other two experiments: The convection regime in the Gulf of Lions 1987 
was almost totally homogenized with only very small yet detectable water mass differences remaining within the deep-mixed regime (Leaman and Schott, 1991). In the other two cases studied, substantial horizontal gradients in water mass properties remained (Fig.7). The difference most likely was due to the fact that in 1987 a very vicious Mistral had thoroughly mixed the water column already in January, one month before the final Mistral mixing studied by SL91. By comparison the convection in the other two cases was more short-lived, not mixing the water column entirely.

This also shows that plumes cannot be understood as mixing the water column vertically in the same way as wind stirring will mix the surface layer: plumes "rain" out of the preconditioning pool and carry water mass signatures down some distance. But since they only cover a few \% of the patch area, cooling has to occur long enough for plumes to thoroughly mix the water column, i.e. at the plume velocity scale $W$ and convection depth $H$ the time scale $\mathrm{T}$ for which near-homogeneity is obtained will have to be several times $\mathrm{H} / \mathrm{W}$.

As discussed in conjunction with Fig.7, convection as observed so far, was found to be vertically nonpenetrative: step-like structures in temperature and salinity occur but not in density. Does this also mean that they do not entrain water from the sides on their way down? Maybe not: in the Greenland Sea it was observed that in plumes out of the cold upper-layer pool the deeper temperatures were increased against their starting values which can be explained by entrainment of warmer water from the sides on the way down, as schematically sketched in Fig.3.c; but that subject needs further study.

At the end of the convection period the newly formed water masses from within the convection region get distributed into the environment by baroclinic instability. Hence the wider region will be peppered with vortices carrying different T,S-signatures than the background. This is documented by deep temperature time series from the Greenland covering two winter periods, $1988 / 89$ with convection (Fig. 14a) and 1989/90 where no convection took place (Fig. 14b), and the following summer periods. In the first year, temperature variance is significantly higher after the convection period than in the second year. Similarly, high variance after mid-February 1992 (Fig.14a) testifies to the fact that convection had taken place in the Gulf of Lions. Thus moored temperature (and conductivity) recorders can serve as convection monitors even if they did never see plumes at their positions; and measurements in the wider convection region even months after the convection period itself can document previous convection activity.

\section{Acknowledgements}

Funding for the Greenland Sea convection studies was obtained by Bundesministerium für Forschung und Technologie, contracts 03R617 and 03PL002A; for the THETIS program by EC/MAST I (contract MAST-CT90-0008). We thank A. Eisele for drafting the figures.

\section{References}

Astraldi, M. and Gasparini, G.P. (1992) 'The seasonal characteristics of the circulation in the north Mediterranean Basin and their relationship with the atmospheric-climatic conditions', J. Geophys. Res., 97 (C6), 9531-9540.

Bethoux, J.P. (1993) this issue.

Bethoux, J.P., L. Prieur und J.H. Bong (1985) 'Evidence of two driving mechanims of the western Mediterranean upper layer circulation: freshwater coastal input and deep water formation', Rapp. Comm. int. Mer Médit., 29 (3), 69-70. 
Bethoux, J.P., Prieur, L. and Bong, J.H. (1988) 'La courant Ligure au large de Nice. The Ligurian current off the French Riviera', Oceanol. Acta, $\mathrm{N}^{\circ} \mathrm{SP}, 59-67$.

Bethoux, J.P., Gentili, B., Raunet, J. and Tailliez, D (1990) 'Warming trend in the western Mediterranean deep water', Nature, 347, 660-662.

Bryden, H. and Kinder, T.H. (1991)'Recent progress in strait dynamics, Reviews Geophys., Suppl. 617-631.

Clarke, R.A. and Gascard, J.-C. (1983) 'The formation of Labrador Sea water. I: Large-scale processes', J. Phys. Oceanogr., 13, 1764-1778.

Clarke, R.A., Swift, J.H., Reid, J.L. and Koltermann, K.P. (1990) "The formation of Greenland Sea Deep Water: double diffusion or deep convection?', Deep-Sea Res., 37, 1385-1424.

Dickson, R.R., Meincke, J.,Malmberg, S.-A. and Lee, A.L. (1988) "The "great salinity anomaly" in the northern North Atlantic 1968-1982', Prog. Oceanog., 20, 103-151.

Font, J., Salat, J. and Tintoré, J. (1988) 'Permanent features of the circulation in the Catalan Sea', Oceanol. Acta, No. SP, 51-57.

Gascard, J.-C. (1973) 'Vertical motions in a region of deep water formation', Deep-Sea Res., 20, 1011-1027.

Gascard, J.-C. (1978) 'Mediterranean deep water formation baroclinic instability and oceanic eddies', Oceanol. Acta, 1 (3), 315-330.

GSP Group (1990) 'Greenland Sea Project - a venture towards improved understanding of the oceans' role in climate', EOS, 71 (24), 750-755.

Heburn, G.W. (1987) 'The dynamics of the western Mediterranean Sea: A wind forced case study', Annales Geophysicae, 5B (1), 61-74.

Hogg, N.G. (1973) 'The preconditioning phase of MEDOC 1969 - II. Topographic effects', Deep-Sea Res., 20, 449-459.

Johannessen, O.M. and S. Sandven (1989) 'SIZEX 89, a prelaunch ERS-1 experiment', Nansen Remote Sensing Center, Techn. Report 23, 39 pp.

Jones, H. and Marshall, J. (1993) 'Convection with rotation in a neutral ocean; a study of open ocean deep convection', J. Phys. Oceanogr. (submitted).

Killworth, P.D.(1976) 'The mixing and spreading phase of MEDOC I', Prog. Oceanogr., 7, 59-90.

Lazier, J.R. (1973) 'The renewal of Labrador Sea water', Deep-Sea Res., 20, 341-353.

Lazier, J.R. (1980) 'Oceanographic conditions at Ocean Weather Ship "Bravo"' , 19641974', Atmosph.-Ocean, 18 (3), 227-238.

Leaman, K.D. and Schott, F. (1991) 'Hydrographic structure of the convection regime in the Golfe du Lion', J. Phys. Oceanogr., 21, 575-598.

Madec, C., Chartier, M., Delecluse, P. and Crepon, M. (1991) 'A three-dimensional numerical study of deep water formation in the northwestern Mediterranean Sea', $J$. Phys. Oceanogr., 21, 1349-1371.

Marshall, 1993 (this issue)

Maxworthy, T. and Narimousa, S. (1992) 'Vortex generation by convection in a rotating fluid', Ocean Modelling, 92 (unpubl. manuscript).

MEDOC Group (1970) 'Observation of formation of deep water in the Mediterranean Sea, 1969', Nature, 227, 1037-1040.

Millot, C. (1991) 'Mesoscale and seasonal variabilities of the circulation in the western Mediterranean', Dyn. Atmosph. Oceans, 15, 179-214.

Nansen, F. (1906) 'Northern waters: Captain Roald Amundsen's observations in theArtic Seas in 1901. With a discussion of the origin of the bottom-waters of the Northern Seas', Videnskabs-Selskabets Skrifter. I. Mathematik-Naturvitenskapelig Klasse, 1906:3, 145 pp.

Prieur, L., Bethoux, J.P., Bong, J.H. and Tailliez, D. (1983)'Particularites hydrologiques et formation d'eau profonde dans le Bassin Liguro Provencal en 1981-1982', Rapp. Comm. int. Mer Medit., 28 (2), 51-53.

Quadfasel, D. and J. Meincke (1987) 'Note on the thermal structure of the Greenland Sea gyre', Deep-Sea Res., 34, 1883-1888. 
Roach, A.T., K. Aagaard and F.Carsey (1993) 'Coupled ice-ocean variability in the Greenland Sea', Atmosphere/Ocean, contribution no. 1380 from NOAA/PMEL (in press).

Rhein, M. (1991) 'Ventilation rates of the Greenland and Norwegian Seas derived from distributions of the chlorofluoromethanes F11 and F12', Deep Sea Res., 38 (4), 485-503.

Rohling, E.J. and Bryden, H.L. (1992) 'Man-induced salinity and temperature increases in the Western Mediterranean deep water', J. Geophys. Res., 97 (C7), 11,191-11,198.

Rudels, B., Quadfasel, D., Friedrich, H. and Houssais, M.-N. (1989) 'Greenland Sea convection in the winter of 1987-1988', J. Geophys. Res., 94 (C3), 3223-3227.

Sankey, T. (1973) 'The formation of deep water in the northwestern Mediterranean', Prog. Oceanogr., 6, 159-179.

Schott, F. and Leaman, K.D. (1991) 'Observations with moored acoustic Doppler current profilers in the convection regime in the Golfe du Lion', J. Phys. Oceanogr., 21, $558-574$.

Schott, F., Visbeck, M. and Fischer, J. (1993) 'Observations of Vertical currents and convection in the central Greenland Sea during the winter of 1988/89', J. Geophys. Res. (in press).

Send, U. and Marshall, J. (1993) 'Integral effects of deep convection', J. Phys. Oceanogr. (submitted).

Swallow, J.C. and Caston, G.F. (1973) 'The preconditioning phase of MEDOC 1969 - I. Observations', Deep-Sea Res., 20, 429-448.

THETIS group (1993) 'Deep convection in the Gulf of Lions and application of acoustic tomography' (in prepration).

Vinje, T.E. (1977) 'Sea ice conditions in the European sector of the marginal seas of the Arctic, 1966-75', Arbok Nor. Polarinst. 1975, 163-174.

Visbeck, M. (1993) 'Konvektion im offenen Ozean', Dissertation, Kiel, 187 pp. 
